\title{
Spatial and Temporal Uncertainty of Rainfall in Arid and Semi-Arid Areas of Ethiopia
}

\author{
Getenet Kebede Urgessa
}

Department of Geography and Environmental Studies, College of Social Science and Education, Wollega University, Post Box No: 395, Nekemte, Ethiopia

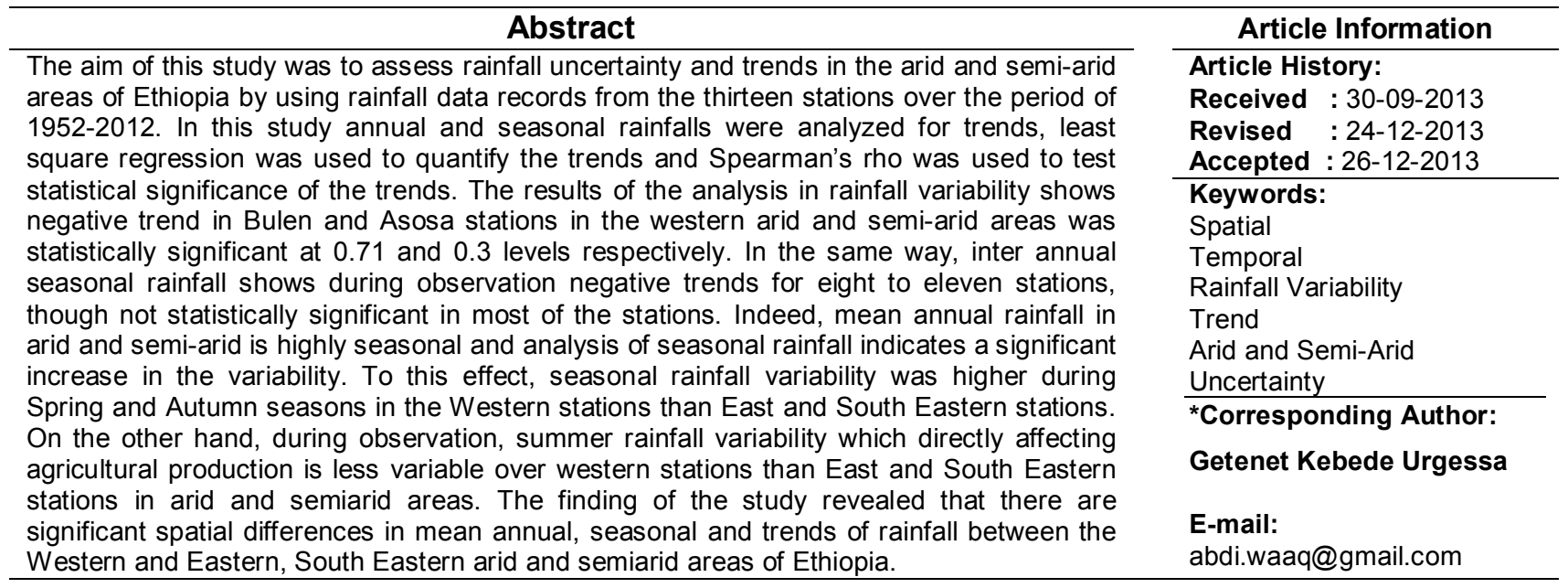

\section{INTRODUCTION}

The arid and semi-arid environments, mainly Eastern, Southern and Western parts of Ethiopia are particularly prone to climate variability. The vast majority of the people in these areas live in miserable condition as far as their economy depends largely on rain-fed agriculture. This shows the sensitivity to variability of rainfall across time and space (Mahumd and Menale, 2007). The livelihoods and welfares of the people are directly dependent on and affected by the climate variability. In this case, climate changes such as rising temperature and rainfall variability are undeniably affect the people in the area. Although exact impact of climate change in Ethiopia has not been exhaustively investigated at large; some studies indicate that the country has experienced climate variability related problems like recurrent drought, desertification and occasional floods (NMSA, 1996). This was consistent with the study by Michael (2006), who suggested that the effects of climate change such as rising temperature and changes in precipitation are undeniably clear with impacts already affecting ecosystems, biodiversity and peoples of East Africa.

Studies reveal that, climate change may have far reaching repercussions to Ethiopia for various reasons.
The most justifications to such effect are the nature of agriculture which is climate dependent (rain-fed), the land escape that is arid and semi-arid occupying the largest part, the fragile high land ecosystem. This is currently under stress due to population pressure, its susceptible vegetation, water and biodiversity to climate change and the spread of vector-borne diseases like malaria in response to climate change (NMSA, 2001).

In other development, Pastoralist and agro-pastoralist constitute about $10-12 \%$ of the total population in Ethiopia, inhibiting significant land areas of arid and semiarid agro-ecologies. In relation to this, the share of arid and semi-arid agro- ecologies is about $60 \%$ of the total national land area (FAO, 1996). In these agro-ecologies, since the rainfall is inadequate and erratic in terms of duration and distribution in temperature, there is high scarcity of the water. Here variability of low or high rainfall can give rise to drought and/or floods both with disastrous socio-economic consequences respectively (Diro et al., 2008). In Ethiopia, rainfall has been highly variable during the last $20^{\text {th }}$ Century (Gissila et al., 2004). Ethiopia's climate variability like daily, seasonally and yearly variations of rainfall and the consequential agricultural and 


\section{Getenet Kebede Urgessa}

socio-economic crises attracted global attention during the aforementioned (Osuman and Saureborn, 2002; Rosell and Holmer, 2007). According to these, sources shortage of precipitation and its space time variability in Ethiopia has caused recurrent and substantial decline in agricultural production which claimed human and animal lives.

Previous study conducted at arid and semi-arid areas the economic effect is mostly on agriculture. For instance, the current condition of chronic hunger is likely to be worse. This is because of the proportion of arid and semiarid lands are expected to increase (by $5-8 \%$ by the 2080s) and partly because of depleted water resources (IPCC, 2007). It is evident that Impacts on agricultural output vary from country to country, with the IPCC projecting reductions in yield in some countries is as much as $50 \%$ by 2020 , with small-scale farmers most vulnerable.

As shown by scholars of the field, the area suitable for agriculture, the length of growing seasons and yield potential of semi-arid and arid areas are expected to decrease because of prolonged high temperatures and periods of drought which force large regions of marginal agriculture out of production (Collier and Goderis, 2007). Such extreme weather is likely to become more frequent with global warming which creates high annual variability in crop production.

Basically, the amount and temporal distribution of rainfall is the most important determinants of Ethiopia's crop production from year to year and rainfall in arid and semi-arid is often erratic and unreliable. The aim of the study is to analyse rainfall variability and trends in arid and semi-arid agro-ecologies of Ethiopia. By using genuine rainfall data, the study examines spatial and temporal patterns in annual, intra- annual and interannual seasons of 13 stations in arid and semi-arid environment of Ethiopia. In fact previously many of the studies conducted on climate variability focused either on rainfall data and on high land part of Ethiopia or only on rainfall data all over the country (Osman and Sauer born, 2002; Sileshi and Demare, 1995). They have studied annual rainfall based on area-averaged rainfall data for north and high land of Ethiopia. Besides, Getenet and Woldeamlak (2009) have studied variations in rainfall extreme event indices in the wettest part of Ethiopia. In addition, Silash and Zanke (2004) have reported via their study, that recent changes in rainfall and rainy days in Ethiopia, where they found no trend over the central, North and North Western parts, but downward trend in the South Western and eastern part of the country from 19652002. Therefore, the current study deviates from the previous studies in two ways: firstly it presents both annual and seasonal rainfall analysis, and secondly the study is conducted on arid and semi-arid parts of Ethiopia which covers $60 \%$ of the total land area using rainfall data from 13 stations.

\section{MATERIAL AND METHODS}

\section{Description of Study Area}

As shown in figure 1, the study area covers stations in the Afar, Somali, Oromia, Benshangul Gumuz and Southern Regional States. The altitude of the stations ranges from 275-1740 m.a.s.l and average annual precipitation generally ranges between $100 \mathrm{~mm}$ at Afar

\section{Sci. Technol. Arts Res. J., Oct-Dec 2013, 2(4): 106-113}

regional state and it can be as high as $1600 \mathrm{~mm}$ in the Besnshangul Gumuz Regional state. Here, average annual temperature ranges from $18{ }^{\circ} \mathrm{C}$ to $34{ }^{\circ} \mathrm{C}$ or higher. According to a study conducted by Deressa, (2006), major soil types include yellow sandy, yellow silty, cambisols, fluvisols and oxidized red clay, but there are extensive areas of alluvium and heavy black soils along the major river valleys.

In the study area, rain-fed crop production is dominated by sorghum, maize, cowpea, groundnuts and sesame. At higher altitudes in this zone, a whole range of crops is grown. They include Teff, Maize, Niger seed, Finger millet, Cowpea and Haricot bean. It covers the lower sections of the main river valleys including cotton, sugarcane, vegetables and tree fruits which are grown on a large scale by irrigation. In the study area, vegetation is very open with much bare ground and the dominant woody plants are various species of Acacia and Wooded grassland where crops are possible only with irrigation. This zone has a potential for livestock rearing and irrigated agriculture (Deressa, 2006).

\section{Data and Methods of Analysis}

The data used for the study were collected from National Meteorological Services Agency of Ethiopia. Monthly rainfall records from 13 stations (Table 1 ) and geographical distribution of stations (Figure 1) were obtained. As mentioned above station records were from the early 1950 s to 2012 . The 13 rainfall records were analyzed at annual and seasonal time steps. All records were scanned for discontinuities, outliers and obvious errors and some removed for erroneous judgment. Number and years with missing data records in each station were listed (Table 1).

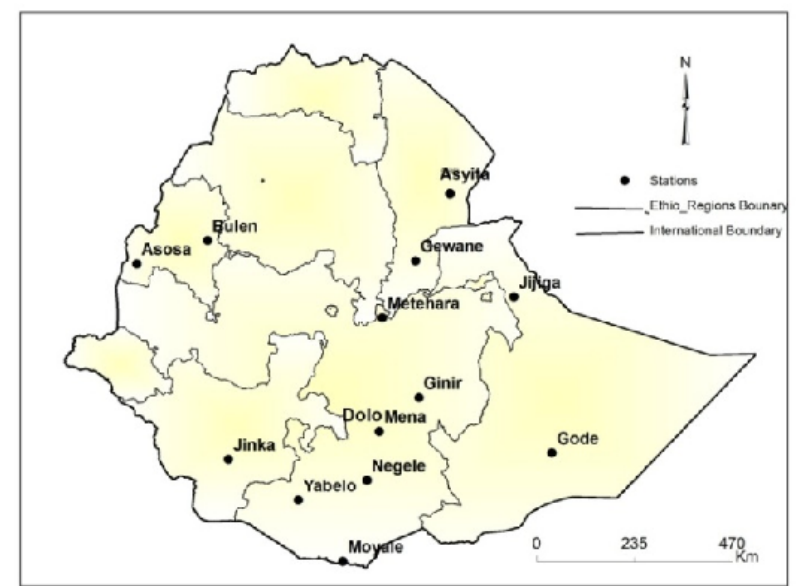

Figure 1: Maps of Ethiopia showing study area and location of the 13 stations used in the study.

In high land of Ethiopia, seasons are unique and classified in to three based on annual rainfall pattern, but for this study seasons are defined according to international season classification. This is because of arid and semi-arid environment is quite different in pattern of rainfall distribution from highland part with manifestation of seasons in the lowland parts of Ethiopia. Therefore, summer season starts in June and ends in August, autumn starts in September and ends in November, winter begins in December and ends in February and spring starts in March and ends in May. 
Table 1: Details of rainfall stations used in the study.

\begin{tabular}{lcclcc}
\hline Stations & $\begin{array}{c}\text { Altitude } \\
(\mathbf{m})\end{array}$ & $\begin{array}{c}\text { Average } \\
\text { Annual rainfall } \\
(\mathbf{m m})\end{array}$ & $\begin{array}{c}\text { Average } \\
\text { Annual } \\
\text { Temp. }\left({ }^{\mathbf{0}} \mathbf{C}\right)\end{array}$ & $\begin{array}{c}\text { Year of } \\
\text { observation }\end{array}$ & $\begin{array}{c}\text { No. of years } \\
\text { with no data }\end{array}$ \\
\hline Assaita & 430 & 163 & 29.5 & $1965-2012$ & $6^{\mathrm{a}}$ \\
Assosa & 1560 & 1137.5 & 21.5 & $1961-2012$ & $7^{\mathrm{b}}$ \\
Bulen & 1500 & 1590.3 & 21 & $1980-2012$ & $5^{\mathrm{c}}$ \\
Delomena & 1400 & 1013.3 & 22.1 & $1982-2012$ & $3^{\mathrm{d}}$ \\
Gewane & 561 & 481.1 & 28.3 & $1980-2012$ & - \\
Ginir & 1750 & 1081.6 & 18.6 & $1955-2012$ & $9^{\mathrm{e}}$ \\
Gode & 275 & 256.4 & 28.8 & $1966-2012$ & $6^{\mathrm{f}}$ \\
jijiga & 1644 & 691.2 & 19.2 & $1952-2012$ & $13^{\mathrm{g}}$ \\
Jinka & 1430 & 1310.3 & 21.5 & $1970-2012$ & - \\
Metehara & 951 & 507.3 & 25.7 & $1984-2012$ & - \\
Moyale & 1019 & 579.1 & 22.5 & $1978-2012$ & - \\
Negele & 1544 & 721.1 & 20 & $1952-2012$ & $2^{\mathrm{h}}$ \\
Yabello & 1740 & 654.7 & 19.8 & $1957-2012$ & $7^{\mathrm{i}}$ \\
\hline
\end{tabular}

Missing years: $a=1971$ and 1989-1993; $b=1990-1993 \& 1997-1999 ; \quad c=1990-1991 \& 1994-1996 ; d=1983-1985$ $\mathrm{e}=1956,1958 \& 1960-1967 ; \mathrm{f}=1987-1992 ; \mathrm{g}=1986-1998 ; \quad \mathrm{h}=1962 \& 1991 ; \mathrm{i}=1980-1985$

It is evident that rainfall in the arid and semi-arid areas of Ethiopia is seasonal and the seasonality can be described through the monthly total as percentages of the total annual rainfall. However, to define the intra-annual variability and its temporal trends, a modified version (De Luis et al., 2000; Ceballos et al., 2004) of the precipitation concentration index $(\mathrm{PCl})$ was applied as:

$$
\mathrm{PCl}=100 \times\left[\Sigma \mathrm{p}_{\mathrm{i}}^{2} /\left(\Sigma \mathrm{p}_{\mathrm{i}}\right)^{2}\right]
$$

Where $\mathrm{P}_{\mathrm{i}}$ is the rainfall amount of the $\mathrm{i}^{\text {th }}$ month; and $\Sigma=$ summation over the $12^{\text {th }}$ months. By this, $\mathrm{PCl}$ values of less than 10 indicate the uniform monthly distribution of rainfall; whereas values between 11 and 20 indicate high concentration/seasonal trend and values above 21 indicate very high concentration/considerable variability of the distribution of monthly rainfall (Ceballos et al., 2004). Therefore, an increase in the $\mathrm{PCl}$ value over the time indicates an increase in the variability of the distribution of monthly rainfall.

In this study, inter-annual variability is evaluated by calculating standardized rainfall anomalies and presenting the results graphically (see Bewket and Conway, 2007). The standardized rainfall anomalies formula will be as follows:

$$
\mathrm{SRA}=\left(P_{\mathrm{t}} \cdot \mathrm{P}_{\mathrm{m}}\right) / \sigma
$$

Where:

$\mathrm{SRA}=$ is standardized rainfall anomaly at year $\mathrm{t}$;

$\mathrm{P}_{\mathrm{t}}=$ is annual rainfall in year $\mathrm{t}$;

$P_{m}=$ is long term mean annual rainfall over a period of observation;

$\sigma=$ is standardized deviation of annual rainfall over the period of observation. The pattern of inter- annual rainfall variability and fluctuations of mean total rainfall is presented graphically for individual stations. There, linear regression is used to quantify trends and the non parametric Spearman's rho was used to test statistical significance of trends.

\section{RESULTS AND DISCUSSIONS}

\section{Annual and Seasonal Rainfall Variability}

The findings of the study indicates that, the mean annual total rainfall in the arid and semi- arid areas of
Ethiopia varies from $163 \mathrm{~mm}$ in Assaita to $1590.3 \mathrm{~mm}$ in Bulen which in fact are located in the North East and Western part of the country respectively (Table 2). Of the 13 stations, seven of them get annual average rainfall $<750 \mathrm{~mm}$. The majority of the stations in the eastern and north eastern part of the country (Assita, Gewane, Gode, Jijiga, Methara) experience annual rainfall amounts of < $750 \mathrm{~mm}$ while majority of the stations in the South, South Eastern and Western parts (Assosa, Bulen, Dolomena, Ginir and Jinka) receive $>1000 \mathrm{~mm}$. Particular stations with higher altitude receive amounts of rainfall over $1000 \mathrm{~mm}$ except Moyale and Yabello. This result is consistent with the study by NMSA (1996) which reported that the mean annual rainfall of extreme lowlands is found to be $<400 \mathrm{~mm}$. Rainfall is bimodal in the North East, East, South and South East arid and semi-arid; and unimodal in the Western arid and semi-arid areas. Similarly, over tropical arid and semi-arid areas rainfall is characterized by high inter- annual variability (Silashi and Zanke, 2004). The rainfall shows moderate to high inter-annual variability as shown by the coefficient of variations (Table 2).

As derived from this study, in Ethiopia, summer rainfall variability which directly affects agricultural production over large areas of the 13 stations exhibited coefficient of variation (CV) over 30\% except in Bulen and Metehara. In this case, summer season over the North East, East, South East stations (Assaita, Dolmena, Ginir, Gode, Negele, Yabello, and Moyale) was extremely variable (CV $>55 \%)$. Spring and autumn rainfall, which is the main rainy seasons in North East, East and South East part of the country, all the arid and semi-arid stations exhibited highly variability of rainfall with ( $C V>20 \%$ and $>33 \%$ ) respectively (Table 2). As indicated indeed, year-to-year variability of the winter (Bega) rainfall was extremely variable for all stations in arid and semi-arid areas. Generally, the winter and spring season rainfalls are more variable than summer and autumn in Western arid and semiarid while winter and summer season rainfalls are more variable than spring and autumn in southern and south eastern arid and semi-arid environments. Conversely summer season rainfall is more variable than the spring and autumn season's rainfall in the Eastern stations of arid and semi-arid environments. 
Table 2: Annual and seasonal rainfall $(\mathrm{mm})$ and coefficient of Variation (CV) over 13 stations.

\begin{tabular}{lcccccccccc}
\hline \multirow{2}{*}{ Station } & \multicolumn{2}{c}{ Annual } & \multicolumn{2}{c}{ Spring } & \multicolumn{2}{c}{ Summer } & \multicolumn{2}{c}{ Autumn } & \multicolumn{2}{c}{ Winter } \\
\cline { 2 - 11 } & Mean & CV & Mean & CV & Mean & CV & Mean & CV & Mean & CV \\
\hline Assaita & 163 & 41.6 & 45 & 70.8 & 79.5 & 60.2 & 24.7 & 86.9 & 13.8 & 131.7 \\
Assosa & 1137.5 & 29.1 & 206.3 & 47.0 & 593.7 & 34.4 & 324.3 & 42.0 & 10.5 & 227.4 \\
Bullen & 1590.3 & 17.2 & 197.5 & 50.6 & 955.2 & 16.1 & 434.7 & 24.7 & 2.9 & 91.9 \\
Dolomena & 1013.3 & 20.3 & 494.1 & 33.3 & 76.3 & 56.2 & 355.6 & 33.5 & 87.3 & 101.6 \\
Gewane & 481.1 & 22.7 & 138.5 & 38.0 & 215.1 & 32.5 & 67.6 & 57.7 & 59.9 & 89.2 \\
Ginir & 1081.6 & 37.1 & 529.4 & 62.8 & 106.7 & 68.9 & 360.7 & 38.8 & 84.6 & 104.7 \\
Gode & 256.4 & 56.9 & 143.5 & 57.5 & 1.4 & 279.8 & 106.9 & 80.2 & 7.1 & 253.9 \\
jijjiga & 691.2 & 39.6 & 235.0 & 51.7 & 248.1 & 42.5 & 159.8 & 51.6 & 48.2 & 110.4 \\
Jinka & 1310.3 & 16.6 & 462.9 & 20.1 & 296.4 & 44.5 & 388.5 & 33.8 & 162.5 & 54.6 \\
Methara & 507.3 & 18.4 & 124.2 & 49.9 & 260.8 & 25.0 & 76.8 & 71.2 & 45.6 & 110.0 \\
Moyale & 579.1 & 34.8 & 290.4 & 46.7 & 30.9 & 61.3 & 196.3 & 72.1 & 61.6 & 69.3 \\
Negelle & 721.1 & 28.3 & 400.1 & 38.6 & 21.6 & 74.5 & 251.7 & 44.4 & 47.7 & 113.8 \\
Yabello & 654.7 & 28.4 & 307.4 & 29.5 & 63.1 & 125.9 & 192. & 45.9 & 92.2 & 70.2 \\
\hline
\end{tabular}

As the result revels, the contribution of summer season rainfall to the annual total is relatively higher in the Western and North Eastern than the Eastern, South East and Southern arid and semi-arid areas of the country. Of course, the contribution of summer rainfall to the annual total ranges from $52.2 \%$ in Assosa in the Western to over $60 \%$ in Bulen which is North East part of Asosa and ranges from $44.7 \%$ in Gewane in North East to over $50 \%$ in Metehara (Table 3 and Figure 1). On the contrary, spring rainfall contributes a considerable rainfall to the annual total in the Eastern, South East and Southern stations of Gode, Negele, Dolomena, Ginir, Yabello, Jijiga and Jinka. This is because the moist, easterly and Southeasterly winds from Indian Ocean produce the spring rainfall in the Southern and Southeastern Ethiopia (see Seleshi and Zanke, 2004). In the same vein, the highest monthly totals rainfall contribution to annual rainfall ranges from $18.4 \%$ in Asosa in the west to over $29 \%$ in Gode which is high proportion of the annual total rainfall (Table 3).

Table 3: Average contribution of the four seasons and the highest monthly rainfall contribution to the annual total (in percent) and the precipitation concentration index $(\mathrm{PCl})$.

\begin{tabular}{|c|c|c|c|c|c|c|c|}
\hline \multirow[b]{2}{*}{ stations } & \multirow{2}{*}{$\begin{array}{c}\text { Spring } \\
\text { Rainfall } \\
(\%)\end{array}$} & \multirow{2}{*}{$\begin{array}{c}\text { summer } \\
\text { Rainfall } \\
(\%)\end{array}$} & \multirow{2}{*}{$\begin{array}{c}\text { Autumn } \\
\text { Rainfall } \\
(\%)\end{array}$} & \multirow{2}{*}{$\begin{array}{c}\text { Winter } \\
\text { Rainfall } \\
(\%)\end{array}$} & \multirow{2}{*}{$\begin{array}{l}\text { Hihest } \\
\text { monthly } \\
\text { rainfall }\end{array}$} & \multirow{2}{*}{\multicolumn{2}{|c|}{$\begin{array}{cc}\mathrm{PCl} & \text { Trend of } \\
\begin{array}{l}\text { (\%) } \\
\text { (corr. with time) }\end{array}\end{array}$}} \\
\hline & & & & & & & \\
\hline Assaita & 27.6 & 48.8 & 15.1 & 8.4 & 26.1 & 14.8 & -0.101 \\
\hline Assosa & 18.1 & 52.2 & 28.5 & 0.9 & 18.4 & 14.4 & 0.039 \\
\hline Bullen & 12.4 & 60.1 & 27.3 & 0.2 & 20.8 & 17.1 & -0.048 \\
\hline Delomena & 48.8 & 7.5 & 35.7 & 8.6 & 20.2 & 14.3 & -0.01 \\
\hline Gewane & 28.8 & 44.7 & 14.1 & 12.5 & 23 & 13.7 & 0.121 \\
\hline Ginir & 48.9 & 9.9 & 33.3 & 7.8 & 22 & 14.1 & -0.058 \\
\hline Gode & 56.0 & 0.5 & 41.7 & 2.8 & 29.8 & 22.2 & 0.135 \\
\hline jijiga & 34.0 & 35.9 & 23.1 & 7.0 & 17 & 11.7 & 0.001 \\
\hline Jinka & 35.3 & 22.6 & 29.7 & 12.4 & 13.9 & 9.5 & 0.003 \\
\hline Methara & 24.5 & 51.4 & 15.1 & 9.0 & 23.1 & 14.3 & 0.125 \\
\hline Moyale & 50.1 & 5.3 & 33.9 & 10.6 & 27.2 & 15.8 & -0.028 \\
\hline Negelle & 55.5 & 3.0 & 34.9 & 6.6 & 27.3 & 19.2 & -0.019 \\
\hline Yabello & 46.9 & 9.6 & 29.3 & 14.1 & 22 & 12.3 & 0.02 \\
\hline
\end{tabular}

To see the long term trend in intra-annual rainfall variability, the $\mathrm{PCl}$ was calculated for the 13 stations and Spearman's rho correlation coefficient was applied to the $\mathrm{PCl}$ to quantify any trend with related degree of significance with time. Thus, accordingly, the $\mathrm{PCl}$ of rainfall in the arid and semi-arid area generally shows moderate to high monthly concentration. In this case most of the stations show an increase in $\mathrm{PCl}$ values, which indicates an increase in the variability of the distribution of monthly rainfall. The $\mathrm{PCl}$ value at Assosa, Gewane, Gode, Jijiga, Jinka, Metehara and Yabello has increased over time but none of them are statistically significant. Therefore, an increase in $\mathrm{PCl}$ indicates an increase in the seasonality of monthly rainfall in arid and semi-arid low land areas of Ethiopia. In the rest of the stations, the PCl value shows decreasing trend though statistically not significant. 


\section{Getenet Kebede Urgessa}

Trend and Variability Analysis of Annual and Seasonal Rainfall

Figure 2 shows, standardized inter-annual rainfall variability at each of thirteen stations. These stations have experienced both dry and wet years over the last thirty years. The proportion of negative anomalies ranges from $33.3 \%$ (Asosa) to $84.7 \%$ (Moyale) of the total number of observations. As the result shows except for Asosa, Jijiga, Delomena, Bulen and Jinka the proportion of negative anomaly was over $50 \%$ of the total number of observations. This result aligns with the result reported by Waldeamlak and Conway (2007) indicating that the proportion of negative anomalies ranged from $39 \%$ to $53 \%$ during the period 1961-2003 for drought proneAmhara Regional State of Ethiopia.

It is shown that significant positive anomaly at Jijiga, Assosa, Gode and Negele occurred during the year of 1976, 2000, 1967 and 1972 respectively. The drought
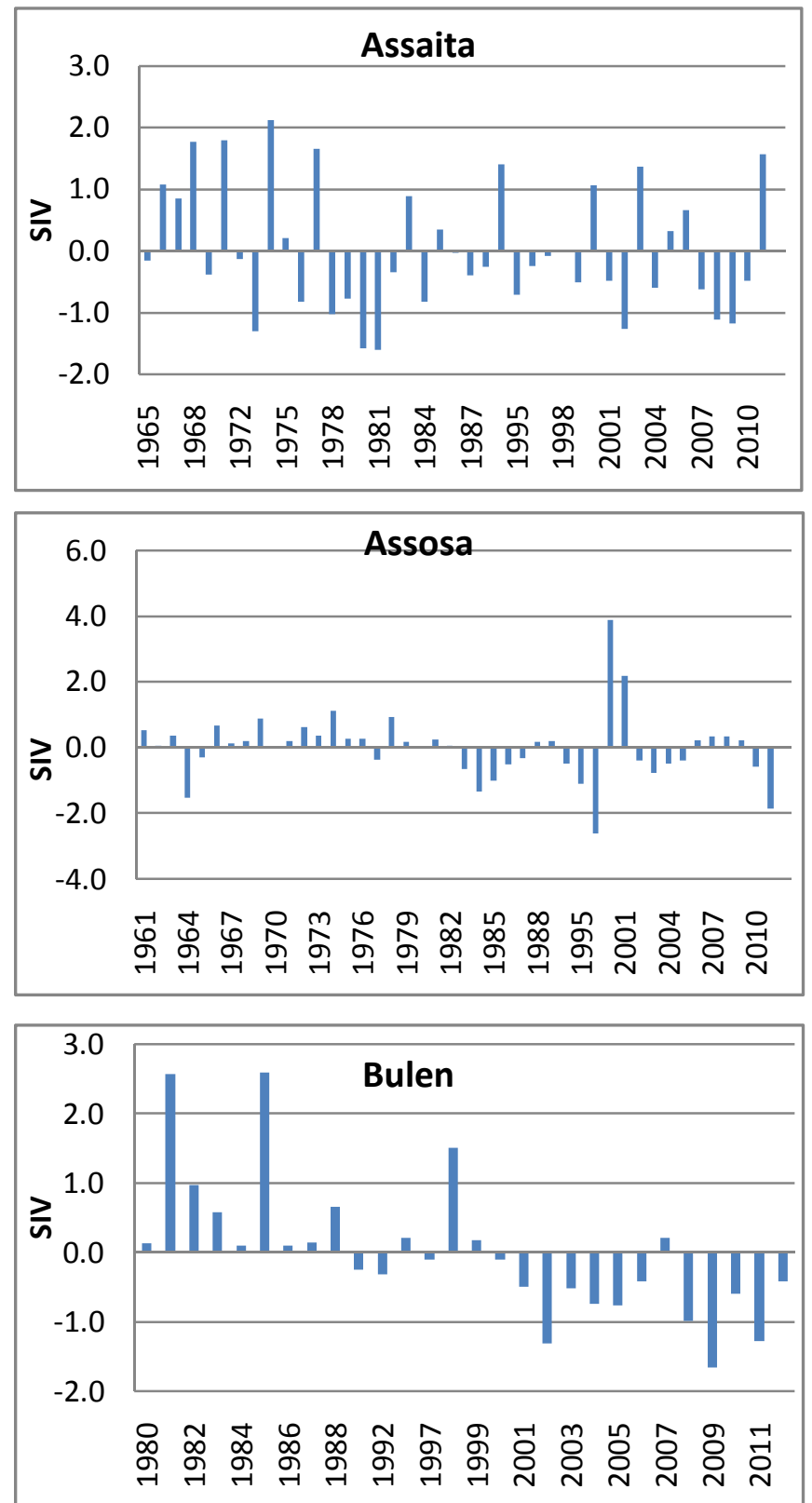

Sci. Technol. Arts Res. J., Oct-Dec 2013, 2(4): 106-113

events that have ravaged the population of Ethiopia have also occurred in most of the stations in 1973, 1984, and 2001 during the observation years (Figure 2). This result is consistent with the study by Degefu's (1987) significant drought events have affected border areas of Ethiopia in 1957-1958, 1964-1965, 1971-1972, and 1983-1984.

Annual rainfall at Eastern (Jijiga) and at Southern (Negele) shows negative anomaly for more than a decade continuously from 1952-1964 and 1982-2012 but in between the decades positive anomaly occurred from the 1965-1981 except in 1973 when negative anomaly has occurred. In Ginir, Jijiga, Bulen, Asosa and Negele annual rainfall has shown negative anomalies during latter years of observations whereas at Gewane negative anomaly experienced in the 1980s. In other stations, annual rainfall shows year to year variability (anomalies); i.e. a year with positive anomaly tends to be followed with years of negative anomalies.
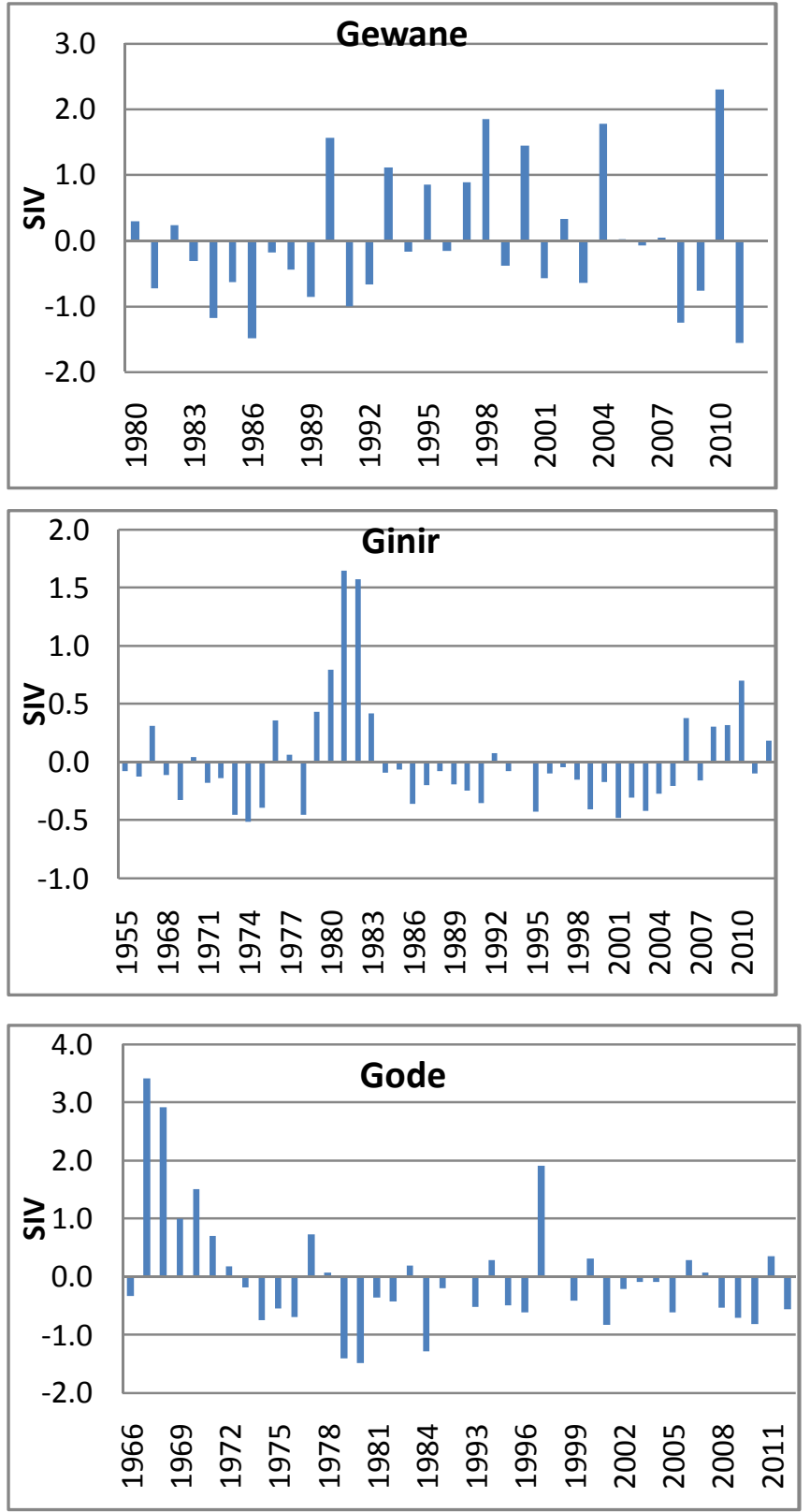
Getenet Kebede Urgessa
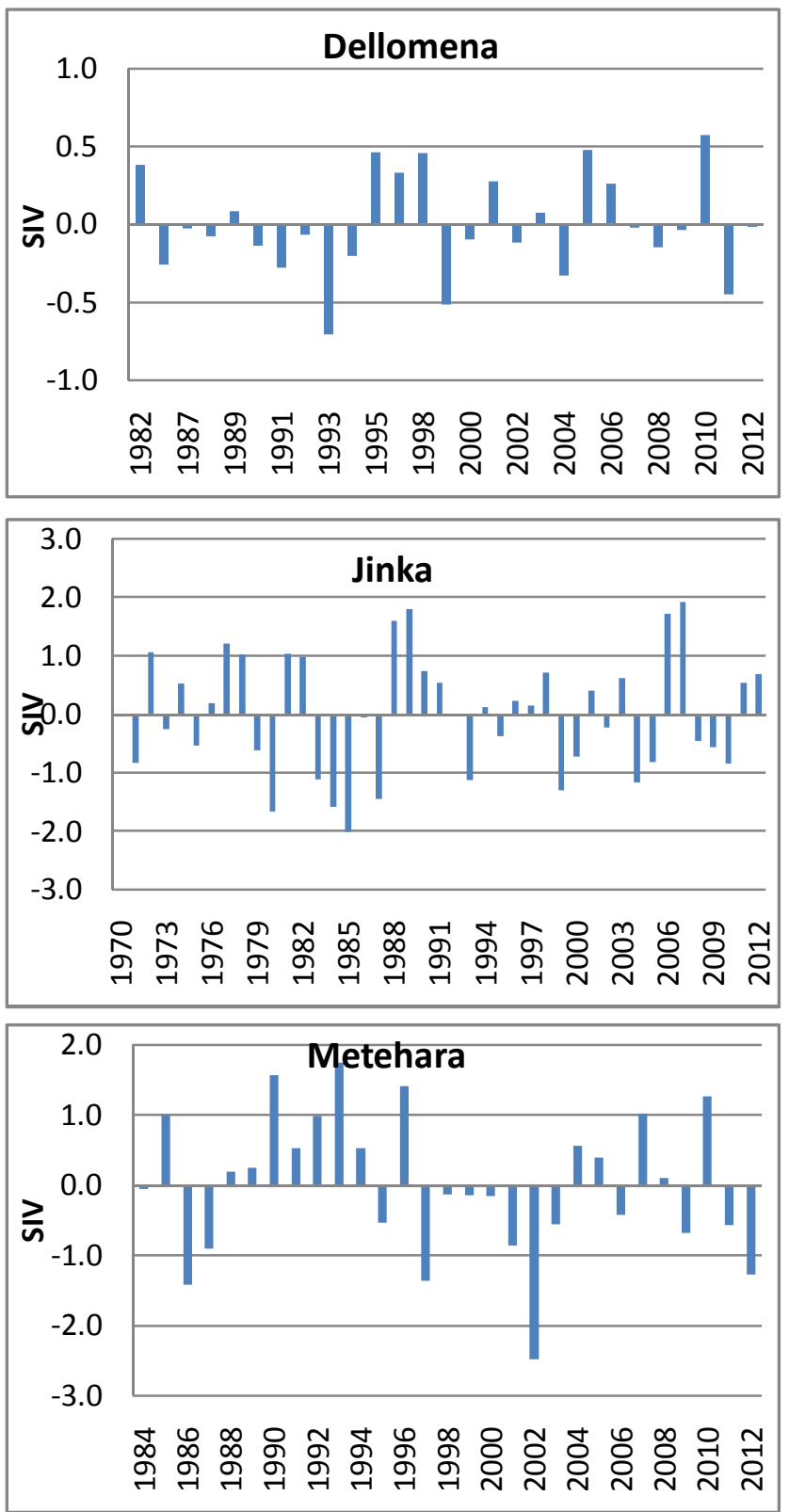

Sci. Technol. Arts Res. J., Oct-Dec 2013, 2(4): 106-113
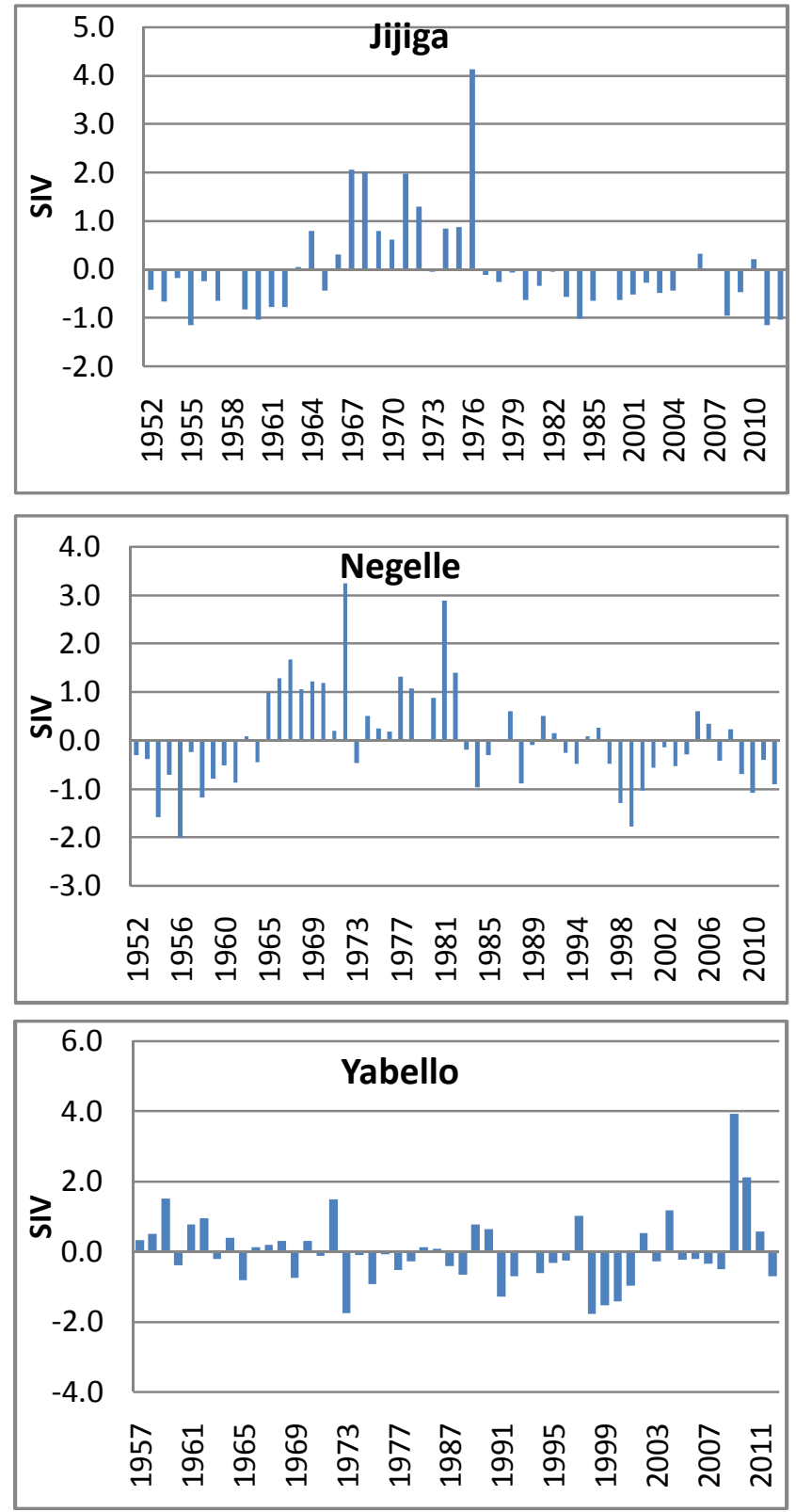

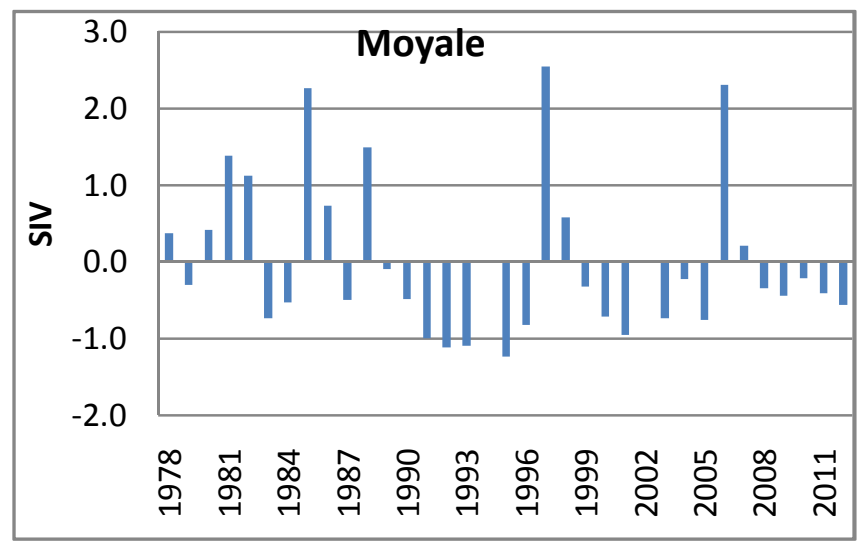

Figure 2: Standardized inter-annual variability (SIV) of rainfall at the 13 stations.

On the top of this, the linear regression and Spearman's rho trend test result show a significant negative trend in the annual and seasonal rainfall totals in some Western and Eastern stations over arid and semiarid areas as obtained from observations. The annual rainfall shows negative trend in ten out of thirteen stations and shows positive trend only in three of the stations (Table 4). The negative trend in Bulen $(227.1 \mathrm{~mm} /$ decade) and Asosa (34.9 mm/decade) in the Western arid and semi-arid areas is statistically significant at 0.71 and 0.3 


\section{Getenet Kebede Urgessa}

levels respectively. The negative anomaly at these stations is relatively decreasing. The negative trend in annual rainfall at Gode and Moyale is also high, but not statistically significant due to inter-annual variability (Table

\section{Sci. Technol. Arts Res. J., Oct-Dec 2013, 2(4): 106-113}

4). In three stations i.e. Dolomena, Gewane and Jinka annual rainfall has shown positive trends, though not statistically significant.

Table 4: Annual and seasonal rainfall trends for 13 stations with long series (LT= Linear trend per decade) during observations.

\begin{tabular}{|c|c|c|c|c|c|c|c|c|c|c|}
\hline \multirow[b]{2}{*}{ Station } & \multicolumn{2}{|c|}{ Annual } & \multicolumn{2}{|c|}{ Spring } & \multicolumn{2}{|c|}{ Summer } & \multicolumn{2}{|c|}{ Autumn } & \multicolumn{2}{|c|}{ Winter } \\
\hline & LT & $\begin{array}{c}\begin{array}{c}\text { Spearman's } \\
\text { rho }\end{array} \\
\end{array}$ & LT & $\begin{array}{c}\begin{array}{c}\text { Spearman's } \\
\text { rho }\end{array} \\
\end{array}$ & LT & $\begin{array}{c}\begin{array}{c}\text { Spearman's } \\
\text { rho }\end{array} \\
\end{array}$ & LT & $\begin{array}{c}\text { Spearman' } \\
\text { s rho }\end{array}$ & LT & $\begin{array}{c}\begin{array}{c}\text { Spearman's } \\
\text { rho }\end{array} \\
\end{array}$ \\
\hline Assaita & -9.6 & -0.16 & -0.8 & 0.02 & -10.9 & -0.29 & -0.2 & 0.10 & 2.2 & 0.20 \\
\hline Assosa & -34.9 & $-0.3^{* *}$ & -7.4 & -0.14 & -19.9 & -0.30 & -12.9 & -0.30 & 2.5 & -0.03 \\
\hline Bullen & -227.1 & $-0.73^{\star *}$ & -58.5 & $-0.52^{\star *}$ & -112.7 & $-0.55^{\star *}$ & -56.2 & $-0.49 * *$ & 0.3 & 0.19 \\
\hline Delomena & 23.4 & 0.11 & -19.3 & -0.10 & 11 & 0.20 & 50.5 & 0.38 & -18.8 & 0.08 \\
\hline Gewane & 18.4 & 0.15 & -14.6 & -0.23 & 28.8 & $0.35^{*}$ & 11.4 & 0.34 & -7.3 & -0.11 \\
\hline Ginir & -6.7 & 0.12 & -32.9 & -0.20 & 1.8 & 0.11 & 8.4 & 0.14 & 16.1 & 0.17 \\
\hline Gode & -43.7 & -0.27 & -30.7 & $-0.43^{\star *}$ & 0.2 & -0.11 & -12.6 & -0.09 & -0.4 & $-0.33^{*}$ \\
\hline jijjiga & -0.20 & -0.06 & 7.5 & 0.15 & -21.8 & $-0.35^{\star}$ & -1.4 & 0.07 & -4.3 & -0.02 \\
\hline Jinka & 7.4 & 0.01 & 5.3 & 0.11 & -6.8 & -0.10 & 2.4 & 0.46 & 6.5 & 0.10 \\
\hline Methara & -19.4 & -0.18 & -24.5 & -0.35 & -6.2 & 0.02 & -21.1 & 0.22 & -9.8 & -0.22 \\
\hline Moyale & -40.6 & -0.20 & -53.8 & -0.33 & -1.1 & -0.12 & 16.7 & -0.04 & -2.5 & -0.08 \\
\hline Negelle & -14 & -0.11 & -10.4 & -0.11 & -1.0 & -0.12 & -0.6 & 0.02 & -1.9 & 0.04 \\
\hline Yabello & -0.9 & -0.15 & -12.3 & -0.23 & 0.5 & -0.13 & -1.2 & 0.14 & -1.1 & -0.05 \\
\hline
\end{tabular}

The summer, autumn and winter season rainfall variability show negative trends for eight stations and spring season rainfall shows negative trend for eleven stations during observations years. As indicated by the result negative trend in spring rainfall at Bulen ( $58.57 \mathrm{~mm} /$ decade) and Gode $(30.7 \mathrm{~mm} /$ decade) is statistically significant at 0.52 and 0.43 levels respectively. The summer rainfall shows declining negative trend at Bulen $(112.7 \mathrm{~mm} /$ decade) and Jijiga $(21.8 \mathrm{~mm} /$ decade) which is statistically significant at 0.55 and 0.35 levels respectively.

It goes without saying as to the finding that it is only in Gewane (28.8 mm/decade) that the summer season rainfall shows positive trend which is statistically significant at 0.35 level. In the same way, intra-seasonal rainfall variability shows significant negative winter season rainfall at Gode. These intra-seasonal rainfalls variability show high negative spring rainfall trend at Ginir and Moyale and high positive autumn rainfall trend at Dolomena, though not statistically significant due to interseasonal fluctuations indeed.

Basically the study has presented a detailed analysis of annual and seasonal rainfall and trends in the arid and semi-arid areas of Ethiopia. The findings of this study is in agreement with those of previous studies conducted over highland of Ethiopia that annual and seasonal rainfall patterns and trends are not consistent (Seleshi and Zanke, 2004; Cheung et al., 2008). The annual rainfall explicates declining negative trend in Bulen (227.1 $\mathrm{mm} /$ decade) and Asosa (34.9mm/decade) is statistically significant at 0.73 and 0.3 levels respectively. Regarding the seasonal rainfall variability, spring rainfall shows negative trend at Gode (30.7mm/decade) and Bulen $(58.5 \mathrm{~mm} /$ decade) statistically significant at 0.43 and 0.52 levels respectively. However, summer season rainfall shows positive trend at Gewane $(28.8 \mathrm{~mm} /$ decade $)$ is statistically significant at 0.35 level.

\section{CONCLUSION}

In conclusion, this study has revealed that there are significant spatial differences in mean annual, seasonal and trends of rainfall between the Western and Eastern, South Eastern arid and semi-arid areas. Thus, seasonal rainfall variability is higher during spring and autumn seasons in the Western stations than Eastern and South Eastern stations. On the other hand, summer rainfall variability which directly affects agricultural production is less variable over Western stations than Eastern and South Eastern stations in arid and semi-arid environments.

\section{ACKNOWLEDGEMENTS}

The author would like to thank the National Meteorological Service Agency (NMSA) for kindly providing of the rainfall data used for the study and Dr. Zeleke Teshome (Wollega University) for language edition and for valuable comments.

\section{REFERENCES}

Ceballos, A., Martinez -Fernadez, J. and Luengo-Ugindos (2004). Analysis of rainfall trend and dry periods on Pluviomertic gradient representative of Mediterranean climate in the Duero Basin, Spain. Journal of Arid Environments 58: 214-232.

Cheung, W.H., Gabriel Senay and Singh, A. (2008). Trends and spatial distribution of annual and seasonal rainfall in Ethiopia. International Journal of Climatology 28: 17231734.

Collier, P. and Goderis, B. (2007). Commodity Prices, Growth and the Natural Resource Curse: Reconciling a Conundrum, CSAE WPS 2007/15

De Luis, M., Raventos, J., Gonzalez -Hidalgo, J.C., sanchez J.R. and Cortina, J. (2000). Spatial analysis of rainfall trends in the Valencia (east Spain). International Journal of Climatology 20: 1451-1469. 


\section{Getenet Kebede Urgessa}

Degefu, W. (1987). Some aspects of Meterological drought in Ethiopia. In drought and Hunger in Africa: Denying Famine a Future, Glantz M(ed). Cambridge University Press: UK; 23-36.

Deressa, T. (2006). Measuring the economic impact of climate change on Ethiopian Agriculture: Ricardian approach. CEEPA Discussion Paper No.25, Centre for Environmental Economics and Policy in Africa, University of Pretoria.

Diro, G.T., Grimes, D.I.F., Black, E., Neill, A.O. and Pardo-Inguzquiza, E. (2008). Evaluation of reanalysis rainfall estimates over Ethiopia. International Journal of Climatology 29(1):67-78.

FAO (1996). Agro-ecological zoning: Guidelines, FAO Soils Bulletin 73. Rome, Italy.

Getenet Kebede and Woldeamlak Bewket. (2009). Variations in Rainfall and Extreme Event Indices in the Wettest Part of Ethiopia. SINET: Ethiopia Journal of Science 32(2): 129-140, 2009

Gissila, T., Black, E., Grimes, D.I.F. and Slingo, J.M. (2004). Seasonal forecasting of Ethiopian summer rains. International Journal of Climatology 24: 345-1358.

IPCC 2007 Climate Change (2007). The 4th Assessment Report of the IPCC. Working Group I The Physical Science Basis Ch. 11 Regional Climate Projections. Intergovernmental Panel on Climate Change.

Mahumd Yesuf and Menale Kassie (2007). Reducing vulnerability in Ethiopia: Addressing the implication of climate change. Unpublished report.

Michael Case (2006). Climate Change Impacts on East Africa, Published in November 2006 by WWF-World Wide
Sci. Technol. Arts Res. J., Oct-Dec 2013, 2(4): 106-113

Fund For Nature (formerly World Wildlife Fund), Gland, Switzerland.

NMSA (1996). Assessment of drought in Ethiopia Meteorological Research Report Series, Vol. 2. NMSA, Addis Ababa, Ethiopia.

NMSA (2001). Initial national communication of Ethiopia to the United Nations Framework Convention on Climate Change (UNCCC). Addis Ababa, Ethiopia.

Osman, M. and Sauerborn, P. (2002). A preliminary assessment of characteristics and long- term variability of rain fall in Ethiopia-Basis for sustainable land use and resource management. Conference on International Agricultural Research for Development. Deutscher Tropentang, Witzenhausen, 9-11 October, 2002.

Rosell, S., Holmer, B. (2007). Rainfall change and its implications for Belg harvest in south Wollo, Ethiopia. Geographical Analysis 89(4): 287-299.

Woldeamlak Bewket and Conway, D. (2007). A note on the temporal and spatial variability of rainfall in the drought prone Amhara region of Ethiopia. International Journal of Climatology 27: 1467-1477.

Yilma Seleshi and Demarée, G.R. (1995). Rainfall variability in the Ethiopian and Eritrean highlands and its links with the southern oscillation index. Journal of Biogeography 22: $945-952$.

Yilma Seleshi and Zanke, U. (2004). Recent changes in rainfall and rainy days in Ethiopia. International Journal of Climatology 24:973-983.

Yilma Sileshi and Camberlin, P. (2006). Recent changes in dry spell and extreme rainfall events in Ethiopia. Theoretical Applied Climatology 83(1-4): 181-191. 